\title{
INSIGHTS FROM BRAND \\ ASSOCIATIONS: ALCOHOL BRANDS AND AUTOMOTIVE BRANDS IN THE MIND OF THE CONSUMER
}

\section{UVIDI U ASOCIJACIJE NA MARKU: MARKE ALKOHOLA I AUTOMOBILA U SVIJESTI POTROŠAČA}

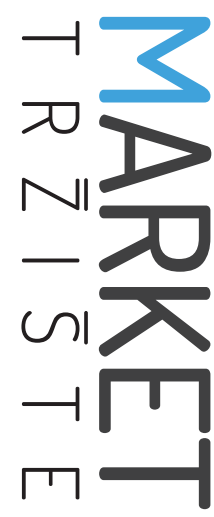

Market-Tržište

Vol. 31, No. 1, 2019, pp. 97-121

UDK 366.1:658.626:629.331(439)

DOl http://dx.doi.org/10.22598/mt/2019.31.1.97

Preliminary communication

\section{László Kovács}

Eötvös Loránd University, Savaria University Centre, Berzsenyi Dániel Square. 2., 9700 Szombathely, HUNGARY, e-mail: kovacs.laszlo@sek.elte.hu

\begin{abstract}
Purpose - The purpose of this paper is to show how the analysis of brand associations can help to elaborate the cognitive position of a brand. The paper compares brand associations of Hungarian consumers in two product categories, automobiles and alcoholic drinks, in two datasets.
\end{abstract}

Design/Methodology/Approach - To obtain a detailed picture of a brand's position in the mind of consumers, free brand associations to 10 alcohol and 13 automotive brands were collected, the associations were categorized, and their frequency and distribution analyzed. K-means clustering was used to identify similarities. Associations within and across product categories are compared, and shifts in associative structures are described.

Findings and implications - The paper shows that associative structures differ across product categories. The two datasets (collected in 2011-2012 and 2015-2016) highlight that brand associations and thus a brand's image change over time and that change is not only due to marketing communication - rather, media news and personal experiences also lead to change. Results confirm that positive and negative associations are likely to be connected to each brand; however, Fetscherin and

\section{Sažetak}

Svrha - Svrha je rada pokazati kako analiza asocijacija na marku može pomoći pri kognitivnom pozicioniranju marke. $U$ radu se uspoređuju asocijacije na marku mađarskih potrošača u dvjema kategorijama proizvoda, automobila i alkoholnih pića,i to u dva skupa podataka.

Metodološki pristup - Za dobivanje detaljne slike pozicija maraka u svijesti potrošača prikupljene su slobodne, nevezane asocijacije za 10 maraka alkoholnih pića i 13 maraka automobila. One su kategorizirane te su analizirane frekvencija i distribucija. Za utvrđivanje sličnosti korištena je K-mean klasterska analiza. Asocijacije su uspoređene unutar i između kategorija proizvoda te su opisani pomaci unutar struktura asocijacija.

Rezultati i implikacije - Rad pokazuje da se strukture asocijacija razlikuju po kategorijama proizvoda. Dva skupa podataka (prikupljena u razdobljima od 2011. do 2012. i od 2015. do 2016.) pokazuju da se asocijacije na marku, a time i imidž marke, mijenjaju tijekom vremena, a to se ne događa samo zbog marketinške komunikacije - vijesti iz medija i osobno iskustvo također dovode do promjena. Rezultati pokazuju da su pozitivne i negativne asocijacije vjerojatno povezane sa svakom markom. No Fetscherinova i Henrichova (2014) matrica samo je djelomično dokazana asocijacijama. Može se zaključiti 
Henrich's (2014) matrix is just partly proved by associations. Finally, it is shown that strong associations can be generated by means of marketing communication, and consistent communication over the years is a prerequisite for creating strong associations.

Limitations - Brand associations are only able to show the current position of brand names in a special cultural/ linguistic and temporal context: thus, the present paper describes the associations for brands in Hungary and in Hungarian in the years 2011-2012 and 2015-2016.

Originality - The paper compares associative structures of Hungarian consumers across and within product categories in two different datasets and shows that associative structures change over time.

Keywords - brands, brand associations, cognitive position, branding, automotive brands, alcohol brands da je dokazano da se snažne asocijacije mogu stvoriti pomoću marketinške komunikacije, a konzistentna komunikacija tijekom godina pretpostavka je za stvaranje snažnih asocijacija.

Ograničenja - Asocijacije na marku mogu samo pokazati trenutnu poziciju naziva marke u specifičnom kulturološkom/lingvističkom i vremenskom kontekstu; stoga rad opisuje asocijacije na marke u Mađarskoj i na mađarskom jeziku, u razdobljima od 2011. do 2012. i od 2015. do 2016.

Doprinos - U radu se uspoređuju strukture asocijacija mađarskih potrošača između i unutar dviju kategorija proizvoda u dva različita skupa podataka i pokazuje da se strukture asocijacija s vremenom mijenjaju.

Ključne riječi - marke, asocijacije na marku, kognitivna pozicija, upravljanje markom, marke automobila, marke alkoholnih pića 


\section{INTRODUCTION}

When hearing the word "brand", we may think of product brands such as clothing (Nike, Versace), food (Heineken, Milka), cosmetic brands (Gilette, Nivea), household electronics (Samsung, Dyson), automotive brands (Volvo, Porsche), or services (booking.com).

Since the end of the $20^{\text {th }}$ century, research on brands and branding has been increasingly in the focus of marketing research. Research has highlighted the benefits of brands in several contexts: for consumers they assure a certain quality, reduce risk and search costs, convey prestige, or show group affiliation (Gordon \& Yoshida, 2016; Keller, 2013; Meffert, Burmann \& Koers, 2002). For companies they enable segmentation, justify higher prices, help to gain market share, and facilitate a unique brand experience and consumer-brand relationship (Gordon \& Yoshida, 2016; Keller, 2013; Meffert et al., 2002). Thus, brands can be the most valuable assets a company owns. This is the reason why the (perceived) value of a brand greatly influences the worth of a company, playing a decisive role in mergers and acquisitions (Keller, 2013).

A brand's value, however, can be perceived in full only if we also take into account the effect a brand exerts on our mind, since brands reside not only in the real world - that is, they are not only the physical products we can touch, but are also part of our mind. Research has shown that brands can be seen as psychological constructs (Franzen \& Bouwman, 2001). As formulated by Kotler and Pfoertsch (2010: 314): "The underlying value of a brand name often is the set of associations, and its meaning for the people. Associations represent the basic for purchase decisions and for brand loyalty."

Although the importance of brand associations is underlined by several scholars and well as being accepted in the brand research community (e.g., Aaker 1991; Franzen \& Bouwman, 2001; Kapferer, 2008; Keller, 2013), associations of a specific brand are in most cases analyzed without comparison across product categories, and the temporal change of brand associations is neglected.

The present paper fills these research gaps by investigating and comparing the associations of 13 automotive and 10 alcohol brands within and across their respective product categories and by analyzing the change of associations over time.

In the first part of the paper, the concept of brand associations is analyzed and it is shown why associations are valuable assets that brands cannot ignore. In the second part, associations are analyzed under various aspects and compared across and within product categories. In the third part of the paper, the results are discussed, managerial implications suggested, and future research problems formulated.

\section{BRAND ASSOCIATIONS}

Brands as cognitive entities unfold their effect in the consumer's mind (cf. Keller, 1998; Kotler \& Pfoertsch, 2006; Meffert et al., 2002). In order to unfold their effect, brands have to be integrated into the mental lexicon ("dictionary of mind") of the consumer - form their connections in the lexicon - and have to achieve a very unique position in it (Kapferer, 2008; Kastens, 2008). The connections a brand has to other words in the consumer's mind are called brand associations: "A brand association is anything 'linked' in memory to a brand" (Aaker, 1991: 109). Associations can be regarded as one of the most important assets of brands (cf. Kapferer, 2008; Keller, 2013).

Research on brand association reveals the importance of associations in several contexts. Brand associations contribute to the differentiation of competing brands, to the success of marketing communication, and to brand equity; moreover, they contain information about positioning, brand image, the brand's competence, its perceived quality, and typical users (Broniarczik \& Alba, 1994; Kapferer, 2008; Keller, 1993; Keller, 2013). Kapferer (2008) emphasizes that associations help in decision making, where Aaker (1991) takes the benefits one step further: in his

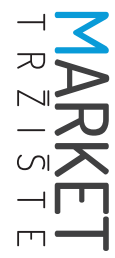


opinion, associations can represent the reason for buying a specific brand.

Brand associations are not equal; they have different strengths, which means that some associations are more characteristic of the brand while others are less so. The strength of brand associations can be measured either by summing up associations or by using complex measures, such as the network characteristics of brand maps (French \& Smith, 2013). The latter method assumes that we know association strength between associations too, the method is therefore only applicable to the study of association strength of complex network structures like brand association maps.

The literature to agrees that stronger associations are preferred to weaker ones because they are easier to elicit and influence the brand's perception more than weak ones can (Esch, 2004; Keller, 1993; Keller, 1998). Since brand names are words, we assume that they collect associations like common words: a strong first association is followed by a second, much weaker association. Based on Schmitt (2012), who assumes that the most important associations of a brand are to the product category, we hypothesize that:

H1: Brand names elicit associations in a similar distribution as common words: a first strong association is followed by a second, much weaker association, and

H1.1: The strongest association is the product category.

Brand associations are not rigid: they change over time. The change can be caused not only by marketing instruments but also by personal experiences to the brand. As Kunkel, Doyle, Funk, Du and McDonald (2016) show, associations towards a sport team - specifically, a new Australian Football League team in their study - change according to the performance of the team. In the case of product brands that exist over a longer time - in our test, part of a century - changes in associations may not be so easily measured, but it can be hypothesized that:
H2: Associations of well-known brands are not rigid, their distribution changes over time.

Associations can be positive or negative: positive ones highlight brand or product characteristics consumers alike (e.g., beautiful), while negative ones highlight the characteristics consumers do not like (e.g., bad smell). Keller (1998) emphasized that brand equity is positive if consumers have positive feelings towards a product. The effects of a positive image are that brands are more profitable, brand loyalty is stronger and growth is easier to obtain (del Rió, Vázquez \& Iglesias, 2001).

Positive and negative feelings towards a brand were systematically described by Fetscherin and Henrich (2014). They proposed a 4-quadrant matrix - weak positive feelings, weak negative feelings, strong positive feelings, strong negative feelings towards a brand - and suggested that consumer brand relationships are measurable along these characteristics. Accordingly, we tested the following hypothesis:

H3: Brand associations highlight feelings towards brands in four disjoint clusters: strong positive, strong negative, weak positive, and weak negative.

Since the seminal work of Gardner and Levy (1955), products and brand have been known as "interwoven sets of characteristics and are complexly evaluated by consumers" (p. 39). Their interwoven character, however, does not mean that for each branded product the product and brand properties are equally important; which one is of greater significance depends on whether the product or the brand is strong (Keller, 1998). With regard to well-known fashion houses, Crawford Camiciottoli, Ranfagni and Guercini (2014) showed that three kinds of associations exist in electronic brand discourse: product-related attributes, non-product related attributes, and designer identity. They found the three fashion brands analyzed to have scored differently on these three dimensions of associations.

From Keller's ideas of strong brand vs. strong product dichotomy and the results of Crawford 
Camiciottoliand others (2014), we hypothesize that:

H4: Associations of the product and of the brand can be distinguished and they show segment-specific distribution.

Individuals do not perceive brands in the same way: they emphasize properties they find important while neglecting others unimportant from their perspective. Batey (2008) argues that brand meaning - the brand's individual picture in the mind of the consumer (Csordás \& Ziegler, forthcoming) - is made of objective and subjective meaning, the former describing sensory impressions such as size and shape, which are invariable across people and the later describing the subjective (individual) perception of a brand. While we might agree with Batey on the objective-subjective distinction, we also assume that these meanings are rather connected to the product. Thus, we hypothesize that these objective and subjective meanings can be captured by associations, therefore:

\section{H4.1: Product associations can be divided into ob-} jective and subjective associations.

The last hypothesis is connected to the origin of associations. Keller (1998) assumed that brand associations are not only generated by marketing instruments but also by word-of mouth and personal experiences, adding that marketing communication is not effective by creating strong associations. Franzen and Bouwman (2001) argued similarly, stating that marketing communication is only effective when it is able to change the brand's position in our mind. In order to prove and refine Keller's position we assume that:

H5: Associations are influenced by marketing communication, the influence is product category-dependent.

\section{DATA COLLECTION AND METHODS}

\subsection{Data collection}

Brand associations can be collected in several ways: by means of a questionnaire seeking as- sociations for only one brand or for a brand and its competitors. Collecting associations can be part of a longer interview, too. The question can be formulated directly ("What do you think of if you hear the brand name Mercedes?"), or indirectly ("To which animal would you compare the brand and why?"). It can be conducted in written or oral form, where it is possible to direct the associations, e.g., "Please name only adjectives!" etc. (for details, see Aaker, 1991; Kastens, 2008; Kovács, 2017). Brand association tests are both effective and valid (cf. Aaker, Kumar \& Day, 2001; Malhotra \& Birks, 2007).

For the present research study, data was collected in two separate data collection periods: 2011-2012 (228 persons, average age 23.1) and 2015-2016 (60 persons, average age 23.75). Data collection was undertaken in Hungary, in Hungarian, mostly from undergraduate students. For each data collection period, the same 100 brand names were presented to the respondents on paper, with the instruction to write down the first five associations to those names (for brand names see Appendix I). They were free, however, to give fewer or no association to the names. As a last step, respondents were asked to indicate whether they know, like, or use the brands.

The decision for collecting five instead of just one association was motivated by the wish of the researcher to get a more heterogeneous set of responses (similarly to De Deyne, Navarro \& Storms, 2013). For the purpose of current analysis, all associations were seen as equal, meaning that no weighing was undertaken (cf. De Deyne et al., 2013) according to the rank of the associations (first to fifth). As scrutinizing the change over time was one of the goals of the research, data collection took place in two periods, 20122013 and 2015-2016, both times during the academic year to have a more balanced dataset. A three-year gap between the collection was chosen to see whether changes occurred in this time period.

Since it was a free association task, respondents had no instruction as to the kind of associations

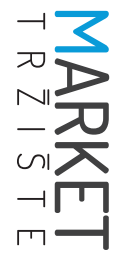


to give (e.g., nouns or names). The decision to conduct free association tests is based on the argument of Keller (1998) that free associations are the simplest and most effective method to study brand associations. There was no time-limit given for a brand or for the whole task - on average, 30-40 minutes were needed to complete the task for all 100 brands. Altogether, almost 60,000 brand associations were collected. At the end of the data collection period, associations were digitalized in Excel, assigning one Excel table to each respondent, also indicating their age and gender.

In the next step, the collected associations were aggregated using a program specially designed for this purpose for each brand, and a weighing of the associations was obtained: identical associations to the brand name were counted, added up and displayed in an Excel sheet. The rank of the association (first to fifth) and gender of the respondents are also indicated (Figure 1). In the process, the data was cleaned and standardized, correcting misspellings and typos.
Fütyülős, Heineken, Johnnie Walker, Soproni, Tokaji, Törley, Unicum) were analyzed.

The two product categories were chosen to represent both Fast Moving Consumer Good (FMCG) brands and consumer durables. Another goal was to include Hungarian brands - or brands connected to Hungary - in both categories. From the ten alcohol brands, seven are of Hungarian origin: Arany Ászok, Borsodi, and Soproni are beer brands, Fütyülős is a liqueur ("palinka"), Tokaji is a renowned DHC wine (Districtus Hungaricus Controllatus = Protected Designation of Origin), Törley is a sparkling wine, and Unicum a herbal liqueur. Due to mergers and acquisitions, most are currently owned by multinational companies: Arany Ászok is owned by Dreher, which is in turned owned by Asahi Group Holdings; Borsodi is controlled by Molson Coors, Fütyülős and Unicum by Zwack (a Hungarian company), Soproni by Heineken, and Törley by Henkell \& Co. (part of Oetker Group); Tokaji DHC wine is made by several smaller and larger wineries in the Tokaj wine region in northeastern Hungary.

FIGURE 1: The most frequent associations to the brand name Audi in the 2015-2016 dataset

\begin{tabular}{|c|c|c|c|c|c|c|c|c|c|c|c|c|c|c|}
\hline & A & $B$ & C & D & $E$ & $\mathrm{~F}$ & G & $\mathrm{H}$ & 1 & $J$ & $\mathrm{~K}$ & $L$ & $M$ & $\mathrm{~N}$ \\
\hline 1 & Válasz & $\mathrm{F} 1$ & $\mathrm{~F} 2$ & F3 & $\mathrm{F} 4$ & F5 & $\begin{array}{c}\text { Férfi } \\
\text { összes }\end{array}$ & N1 & N2 & N3 & N4 & N5 & $\begin{array}{c}\text { Nõ } \\
\text { összes }\end{array}$ & Összes \\
\hline 2 & autó & 7 & 0 & 1 & 0 & 0 & 8 & 14 & 1 & 0 & 0 & 0 & 15 & 23 \\
\hline 3 & német & 2 & 2 & 5 & 1 & 0 & 10 & 1 & 4 & 0 & 0 & 0 & 5 & 15 \\
\hline 4 & Gyõr & 3 & 2 & 3 & 0 & 0 & 8 & 0 & 1 & 0 & 1 & 0 & 2 & 10 \\
\hline 5 & gyors & 0 & 2 & 0 & 4 & 0 & 6 & 1 & 0 & 0 & 0 & 1 & 2 & 8 \\
\hline 6 & minõség & 2 & 1 & 1 & 1 & 0 & 5 & 0 & 2 & 0 & 0 & 1 & 3 & 8 \\
\hline 7 & drága & 0 & 2 & 1 & 0 & 1 & 4 & 0 & 1 & 2 & 0 & 0 & 3 & 7 \\
\hline
\end{tabular}

Note: Válasz=answer; Férfi összes=male total; Nő összes=female total; Összes=total. F1-F5; N1-N5 - first to fifth rank associations by male (F) and female (N) respondents. Autó=car; német=German; Győr=a city name in Hungary, with a production site of Audi; gyors=fast; minőség=quality; drága=expensive. Car ('autó') as an answer came up altogether 23 times, 8 times from male, 15 times from female respondents; with males it ranked in the first (7 persons) and third ( 1 person) place, with females in the first (14 persons) and second (1 person) place.

Source: own calculation.

In the current analysis, automotive brands (Alfa Romeo, Audi, BMW, Citroën, Ferrari, Fiat, Mercedes, Opel, Peugeot, Porsche, Suzuki, VW, and the Hungarian bus brand Ikarus) and alcohol brands (Arany Ászok, Borsodi, Finlandia,
Their names - and perceived country-of-origin remained unchanged (see H1.1).

Hungary has almost no consumer durable production of his own; however, it hosts the automobile factories of Audi (Győr), Mercedes 
(Kecskemét), Opel (Szentgotthárd), and Suzuki (Esztergom). Ikarus is a renowned bus brand of Hungary, extensively exported to and used in former Eastern bloc countries. The company still manufactures buses and trolley buses.

\subsection{Categorizing associations}

To analyze brand associations, it is important to categorize them. Establishing categories, in which associations can be handled together, is necessary because a great variety of associations can occur for a brand name (cf. Aaker, 1991; Franzen \& Bouwman, 2001; Kastens, 2008). For example, in the 2012-2013 dataset, numerous different associations were collected for the brands scrutinized: 111 for Törley, 149 for Alfa Romeo and Ferrari, 167 for Heineken, and as many as 197 for BMW. It is impractical to analyze and directly compare 100 or 200 individual associations, especially across product categories. How does one compare, for example, Heineken - Gösser with Ferrari - Lamborghini? Obviously, you cannot compare Lamborghini with Gösser, except by saying that both are brand names. Creating an association category "brand names - competitors" into which both associations belong, however, you have a possibility to compare these dimensions of each brand: for example, how many competitors occur according to one's associations. Therefore, a researcher creates categories for associations in order to be able to directly compare brands with each other and because in this way key factors and differences of a brand's associative structure can be captured.

There is no unified framework for categorizing brand associations. Although some researchers present examples for possible categorizations (e.g., Aaker, 1991; Franzen \& Bouwman, 2001), how these are related to empirical research remains unknown: are the categories based on empirical data or do they just represent a possible categorization method with no or just a slight empirical support?

Aaker (1991: 115), for example, shows 11 possible categories for associations (Table 1). Drawing some examples from the collected data of current research, it would nevertheless not be easy to categorize the following associations: Fa forest (from the meaning of the Hungarian word $f a=$ tree); Heineken - I hate beer; Gucci - guppy.

\section{TABLE 1: The association categories of Aaker}

\begin{tabular}{|l|}
\hline Brand associations \\
\hline Product attributes \\
\hline Intangibles \\
\hline Customer benefits \\
\hline Relative price \\
\hline Use / Application \\
\hline User / Customer \\
\hline Celebrity / Person \\
\hline Life style / Personality \\
\hline Product class \\
\hline Competitors \\
\hline Country / Geographic area \\
\hline
\end{tabular}

Source: Aaker, D. A. (1991). Managing Brand Equity. New York, NY: Free Press.

The categories of Franzen and Bouwman (2001) are more deeply elaborated; more than 100 possible categories altogether exist in three contexts: (i) brand values, (ii) brand meanings, and (iii) company behind the brand. It is hard to distinguish amongst the three different contexts. Categorizing associations in this case means picking one context. This is useful if the associations in a given context are important, but all the other contexts are partly neglected in this case. In fact, all three contexts exist together at the same time as different facets of the same brand.

Franzen and Bouwman's categories also provide little help in categorizing associations that are related to the word meaning or to the sound of the brand name. Such associations are important, however, because in some cases they arise in large numbers and represent assets a brand can build on.

A kind of categorization based on empirical data was done by Kastens (2008) in two case

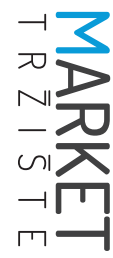


studies, in which she subsumed associations under specific basic concepts derived from the collected associations. The categories formed in this manner, however, refer to the collected German associations. This is the reason why Kastens' categories, while providing a valuable insight into how association categorization processes take place, cannot be used for general investigations.

For the reasons mentioned above, it was decided that a new categorization for associations had to be created for present research. That decision was made to follow and refine Kastens' method. In a first step - based on Aaker (1991), Franzen and Bouwman (2001), and Kastens (2008) - three main categories of associations were formed: associations to the brand, associations to the product, and associations of the user and usage. To create further adequate cat- egories based on empirical data, in the second step two brands from each product category were chosen and then, based on the collected associations, possible categories were created by two researchers independently. Where necessary, subcategories such as "logo", "slogan" were created or new main categories were introduced. After the first run, categories of the two researchers were compared, with identical ones being accepted while different ones were discussed.

Finally, six main categories were formed: I. brand associations; II. product associations - objective; III. product associations - subjective; IV. user and usage associations; $V$. association to the word form; and VI. miscellaneous associations. The six main categories were divided into 20 categories (Table 2), which were again divided into 0-6 subcategories.

\section{TABLE 2: Categories of associations}

\begin{tabular}{|c|c|}
\hline Associations related to & Examples \\
\hline Brand & Ferrari - horse \\
\hline Country / Geographic area of origin & Mercedes - Germany \\
\hline Type, sub-brand (categorization lower level) & Fiat - Punto \\
\hline Product / brand category (categorization higher level) & Opel - car \\
\hline Price & Heineken - expensive \\
\hline Objective / physical product attributes & BMW - wheels \\
\hline Subjective / relative / abstract product attributes & Ferrari - cool \\
\hline Sensory impressions & Arany Ászok - tastes good \\
\hline User / Customer & Alfa Romeo - rich people \\
\hline Usage characteristics & Borsodi - friends \\
\hline Usage impact & Arany Ászok - drunken \\
\hline Product manufacturing & Audi - factory \\
\hline Attitude & Audi - favorite car brand \\
\hline Competitors and other brands & Arany Ászok - Gösser \\
\hline Advertisement, PR & Unicum - swimming man \\
\hline Brand in the pop culture & Peugeot - Taxi (movie) \\
\hline Meaning (semantics) of the name & Fa - tree \\
\hline Phonetics of the name & Gucci - guppy \\
\hline Wrong association & Ferrari - red color comes from tractor colors \\
\hline Miscellaneous / not to be categorized & Mercedes - tuning fork \\
\hline
\end{tabular}

Note: Examples are taken from the datasets and translated into English.

Source: own calculation. 
The author had to categorize various levels in order to be able to answer different research questions to avoid creating a new resource- and time-consuming categorization every time. For the purpose of the present research study, only the main categories (I.-VI.) are analyzed, except for Figure 6 and Figure 10. Then, the actual schematization of categories was undertaken for each association of each brand individually, again by two researchers independently. After that process, inter-rater reliability was calculated (Cohen's Kappa k=0,86) and, where necessary, the categorization was discussed. The entire complex process of categorization is described in detail in 17 steps by Kovács (2017).

\subsection{Data analysis}

Data was collected and analyzed in Excel sheets, as described above. Tableau was used for data visualization, and k-means clustering (Lloyd's algorithm with squared Euclidean distances) for clusters; for the optimal number of clusters the Calinski-Harabasz criterion was used. For a detailed description of the methods, see the explanation of Tableau (available online at: https:// www.tableau.com; https://onlinehelp.tableau. com/current/pro/desktop/en-us/clustering.htm).

\section{RESULTS: ANALYSIS OF BRAND ASSOCIATIONS}

\subsection{Strongest associations}

$\mathrm{H1}$ : Brand names elicit associations in a specific distribution: a first strong association is followed by a second, much weaker association.

As a first step, the distribution of the associations is analyzed. In the current research, a strong first association was observed in most cases, followed by a much weaker second association (Figure 2). It is observable, however, that alcoholic drinks have a steeper slope - which indicates that these brands have a stronger first association than do automotive brands. The strongest associations of automotive brands (when both datasets and all analyzed brands are included) are $30 \%$ weaker on average than those of alcoholic drinks.

FIGURE 2: Distribution of the 25 most frequent associations for the brands Audi, Ferrari, Fütyülős, Heineken, Suzuki, and Tokaji in the 2011-2012 dataset

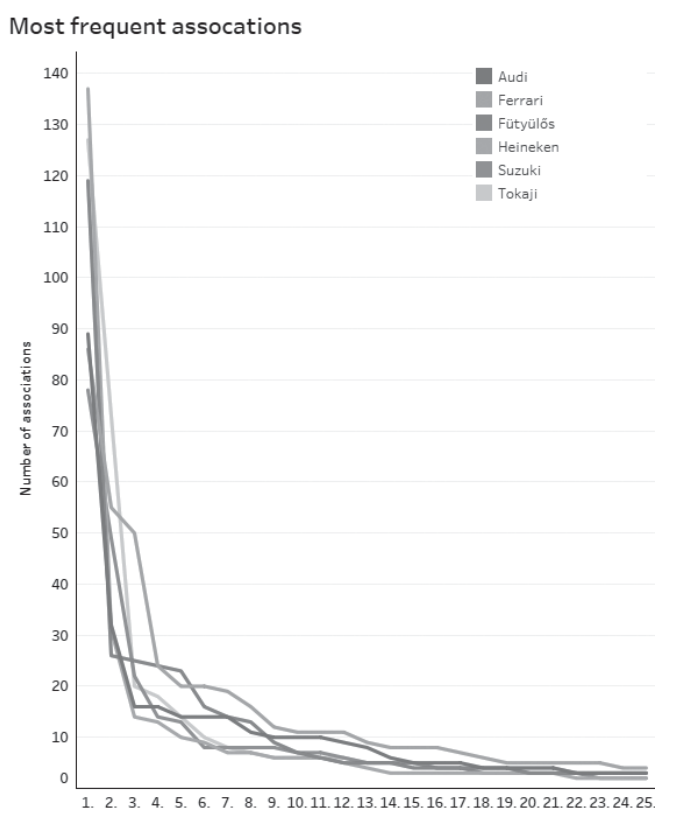

Source: own calculation.

Still, it does not mean a smaller variety in associations (the difference in variety of the two product groups is less than $10 \%$ ), which is only possible when the second, third, fourth, etc. associations of alcohol brands are weaker than those of automotive brands. This gives the insight that the distribution of strong associations is connected to product category.

A closer look at the collected data reveals that in some cases a strong association is followed by a similar strong association. It was observed in the case of the herbal liqueur Unicum, where the first association "alcohol" (mentioned in 44 cases) was followed by "bitter" as the second strongest association (mentioned in 43 cases). After analyzing 33 brands of the corpus (33\% of the

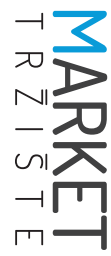


dataset), 3 brands were found to have the same distribution (a strong first association followed by a strong second association): the abovementioned Unicum; Ferrero: "chocolate", "sweet"; Maybelline: "lipstick", "New York". This indicates, that although most brands have a very strong first association and a much weaker second one, in some cases brands have two, similarly strong associations instead of one strong one. One of them is product category, the second one, however, refers to a specific characteristic of the given brand.

While it is observable, that more than $90 \%$ of the analyzed brands have a strong association followed by a second, much weaker association, in 3 cases out of 33, the second association was almost as strong, as the first one. Thus, $\mathrm{H} 1$ is accepted as the distribution stated in $\mathrm{H} 1$ seems to be characteristic for most brand names.

H1.1: The strongest association is the product category.

FIGURE 3: Most frequent associations

\begin{tabular}{|c|c|c|}
\hline 2011-2012 & $2015-2016$ & Márka \\
\hline alkohol & alkohol & Unicum \\
\hline \multirow[t]{11}{*}{ autó } & autó & Alfa Romeo \\
\hline & & Audi \\
\hline & & BMW \\
\hline & & Citroën \\
\hline & & Fiat \\
\hline & & Mercedes \\
\hline & & Opel \\
\hline & & Peugeot \\
\hline & & Porsche \\
\hline & & Suzuki \\
\hline & & vW \\
\hline bor & bor & Tokaji \\
\hline busz & busz & Ikarus \\
\hline pálinka & pálinka & Fütyülős \\
\hline pezsgõ & pezsgõ & Törley \\
\hline piros & piros & Ferrari \\
\hline \multirow[t]{4}{*}{ sör } & sör & Arany Ászok \\
\hline & & Borsodi \\
\hline & & Heineken \\
\hline & & Soproni \\
\hline vodka & vodka & Finlandia \\
\hline whiskey & whiskey & Johnnie Walker \\
\hline
\end{tabular}

Note: márka=brand; alkohol=alcohol; autó=car; bor=wine; busz=bus; pálinka=pálinka / fruit brandy; pezsgő=sparkling wine; piros=red; sör=beer; vodka=vodka; whiskey=whiskey. Source: own calculation.
The most frequent associations are the associations to the product category for almost each brand (Figure 3), indicating that the strongest cognitive connection of brand names is categorization to a higher-level product category. The only exception is Ferrari, which is associated with the color "red", showing that the association to this brand characteristic is exceptionally strong.

Strong associations can help in identifying the strengths and weaknesses of a brand. In the case of Ferrari, the brand is strongly associated with red color. In most cases, if one asked consumers to name a red sports car / supercar brand, the answer would be Ferrari. The color red alone has been known in association tests, where common words serve as stimuli, to be capable of eliciting the Ferrari brand name (cf. Kovács, 2017). This could be, for example, an indicator of successful branding and successful advertisements (compare also Figure 8 for the strength of the brand associations of Ferrari). However, in the case of Ferrari, successful advertisements cannot account for the strong association since customers see almost no explicit Ferrari advertisements. Such strong association emerges presumably because the brand seems to be part of our shared cultural knowledge.

Ferrari's branding strategy can be seen as a good example of a consistent brand image creation for decades, since the strongest associations collected in the dataset ("red", "formula 1", "car", "Schumacher", "fast", "horse", "expensive", "Italy", "luxury" in the 2011-2012 dataset; and the same ones except for "Schumacher" in the 20152016 dataset) are exactly those which Ferrari wants to emphasize in his branding strategy: car racing, fast luxury sports-cars and brand symbols like the color rosso corsa and the prancing horse (di Montezemolo, 2003). Analyzing how and why these associations are created can help to describe a branding strategy which ensures the creation of unique, stable associations.

The association to the country of origin was a strong association to every brand: in $83 \%$ of the cases it was the $2^{\text {nd }}-10^{\text {th }}$ strongest associ- 
ation. The former Hungarian alcohol brands, according to the association (country of origin: magyar - Hungarian), are therefore perceived as Hungarian brands. However, in some cases of alcohol brands the origin was twofold: Finlandia is both Finnish and Russian - the later attributable to the product category (vodka), while Heineken is perceived as being both Dutch and German.

The automotive brands Audi, Mercedes, Opel, and Suzuki also elicit Hungarian city names Győr, Kecskemét, Szentgotthárd and Esztergom, respectively - where their factories are located, which means these brands are perceived as Hungarian, but not so strongly as Suzuki. In the case of Suzuki, the association to the origin was both Japanese (4 ${ }^{\text {th }}$ strongest association) and Hungarian ( $7^{\text {th }}$ strongest association) in the 2011-2012 dataset. The Hungarian country-of-origin effect of Suzuki is reinforced by the previous slogan of the brand "A mi autónk" ("Our car"), which can be regarded as emotional branding that elicits brand attractiveness and brand loyalty (cf. Ozretić Došen, 2014). The special cogni- tive position of Suzuki and its "Hungarian" origin must be traced back to the abovementioned slogan ("Our car") and to emotional branding, since both Suzuki and Opel opened their factories in Hungary in the early 1990s (in 1991 and 1992, respectively), while Opel was not perceived as a Hungarian brand (see also H5).

Since the strongest association in $96 \%$ of the cases except for Ferrari was to the product category, H1.1. was accepted.

\subsection{Associations change over time}

H2: Associations of well-known brands are not rigid, their distribution changes over time.

As the next step, we compared the associations for each main category in the two datasets (Figure 4 and 5). It is observable that the distribution of the associations can change over time. Shifts in association structures can be regarded as normal because associations can move along an axis, e.g. from tangible values of a product to intangible values of a brand (Kapferer, 2008: 56).

FIGURE 4: Percentage of associations by main category, automotive brands

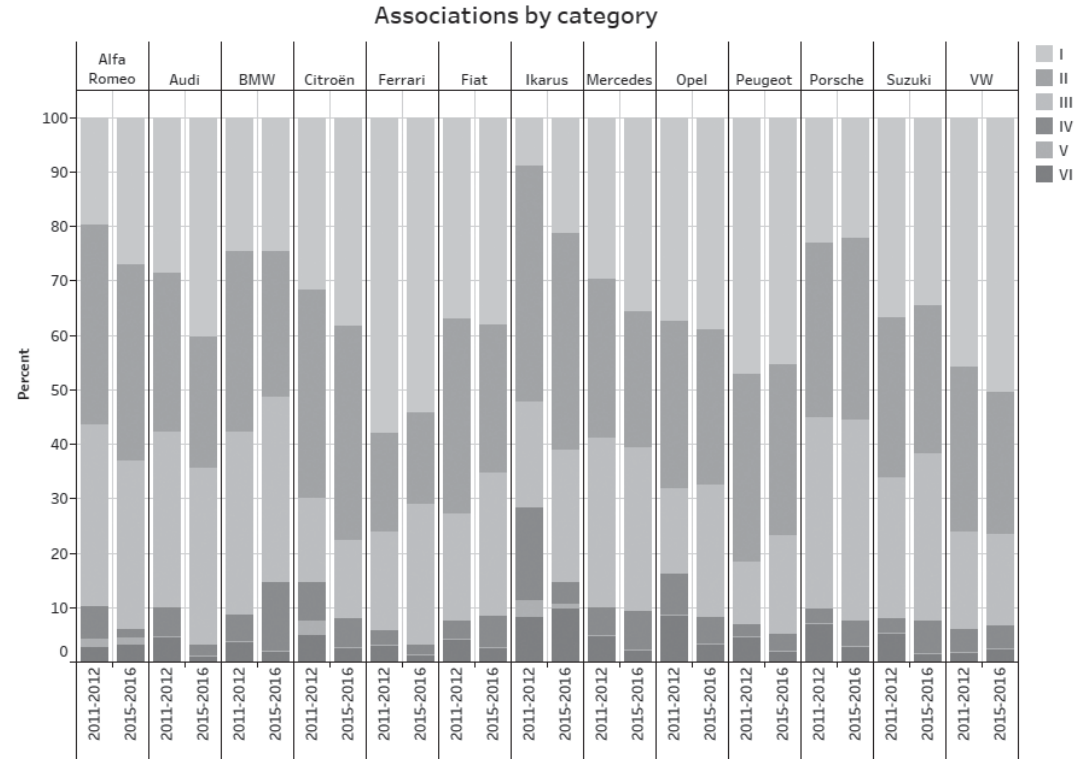

Note: Categories: I. brand associations; II. product associations - objective; III. product associations - subjective; IV. user and usage associations; V. association to the word form; VI. miscellaneous associations.

Source: own calculation. 
László Kovács

\section{FIGURE 5: Percentage of associations by main category, alcohol brands}

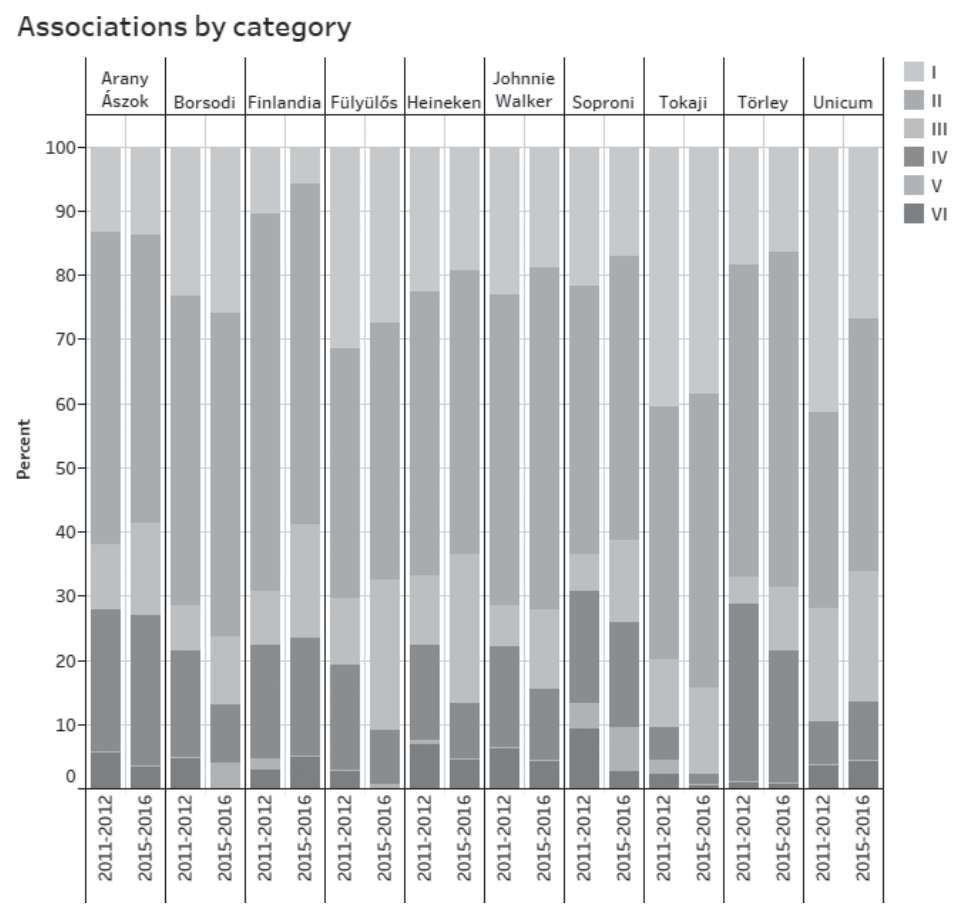

Note: Categories: Categories: I. brand associations; II. product associations - objective; III. product associations - subjective; IV. user and usage associations; V. association to the word form; VI. miscellaneous associations.

Source: own calculation.

Comparing data across product categories, it is clear that user and usage associations play a crucial role in the positioning of alcohol brands but almost no or just a subordinate role in the positioning of automotive brands. Meanwhile, the only bus brand between the automotive brands (Ikarus) displays a high percentage of associations on use, with that fact being due to the type of vehicle: automotive brands vs. a bus brand.

In the case of Ikarus, the usage image in 20112012 is mostly connected to the older Ikarus buses at the time, that is, the Ikarus 200-series, which were designed and mostly manufactured in the 1970s and 1980s and represented a standard of that era (Ikarus, 2016). In that period and until the 1990s, almost all buses in Hungary both for urban and long-distance traffic - were of the Ikarus brand. They were still operating in large numbers during the first decade of the $21^{\text {st }}$ century, but their number has decreased as they have been replaced by newer models. Therefore, in 2012-2013 almost all respondents had personal experience with the brand, while the "younger" generation had fewer encounters with the brand in 2015-2016, thus associations to usage decreased dramatically in 2015-2016. It must be stated that the associations to Ikarus are in general twofold: on the one hand, they are negative ones complaining about the quality and smell of the busses, while others are rather positive, nostalgic ones.

To evaluate changes in a brand's associations, it is useful to compare it with changes in customer behavior or with other events influencing brand perception. In the case of $\mathrm{VW}$, for example, the diesel scandal of September 2015 accounts for the less positive image, with associations includ- 
ing "scandal", "diesel scandal", and "pollution". The speed of change is remarkable: while the data collection period was just 2 weeks after the first news of the diesel scandal broke, these associations appeared in a relatively large number (5\%). This shows that even the strongest brands can suffer from negative associations, and positive branding of decades can be derailed in a matter of days or weeks.

The case of Ikarus and VW shows that a brand's image and the associations it invokes are not exclusively created by means of marketing communication: news and personal experiences also contribute to a brand's cognitive position.

H2 was accepted, as we have seen that associations are not rigid and that they change over time; but a much more important finding is that this change can occur both slowly (over years, in the case of Ikarus) or quickly (within days in the case of $\mathrm{VW}$ ).

\subsection{Positive and negative associations}

H3: Brand associations highlight feelings towards brands in four disjoint clusters: strong positive, strong negative, weak positive, and weak negative.

The categorization of associations can also occur in a different context, where associations are categorized according to whether they are positive or negative ones (cf. Malhotra \& Birks, 2007). Positive ones can include associations such as "I love it" or "beautiful", and negative ones "smells bad" or "tastes bad". Positive and negative associations are important because they can influence purchase decisions (compare e.g., the influences of positive and negative word-of-mouth on purchase decisions in East, Hammond \& Lomax, 2008).

The analysis of positive and negative associations in the two datasets reveals that some

FIGURE 6: Positive and negative associations, alcohol brands

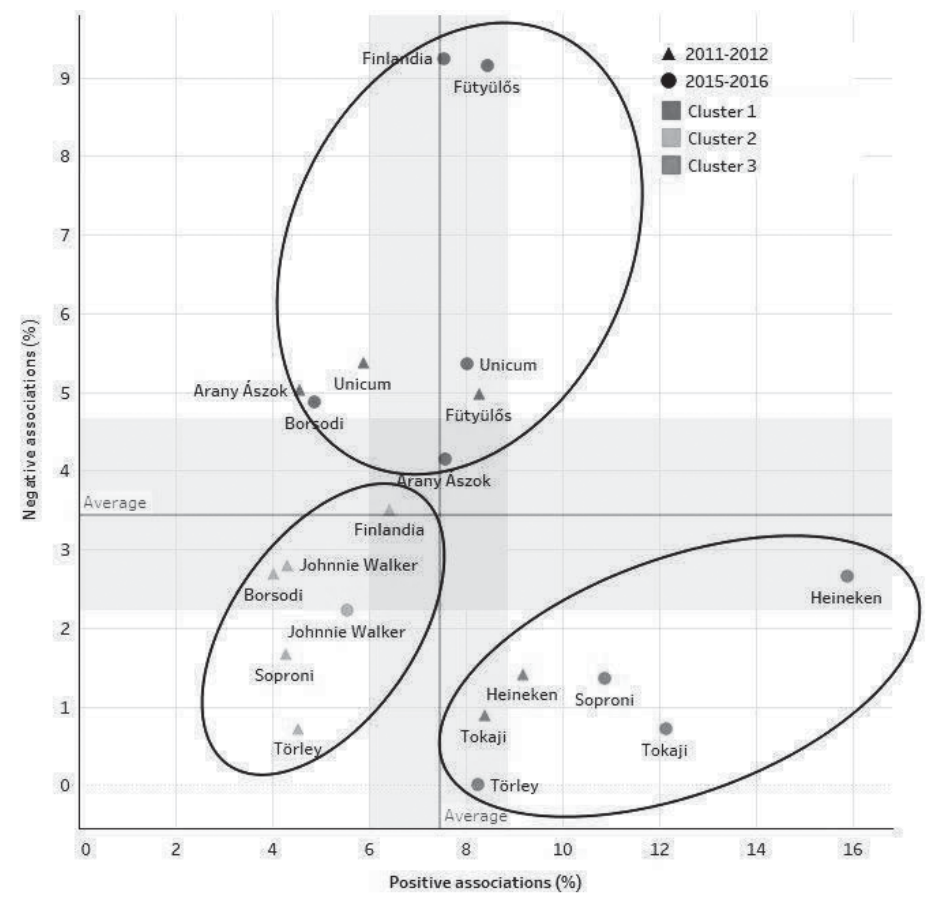

Note: Clusters: k-means clustering; algorithm used: Lloyd's algorithm with squared Euclidean distances; for the optimal number of clusters the Calinski-Harabasz criterion was used.

Source: own calculation. 
László Kovács

FIGURE 7: Positive and negative associations, automotive brands

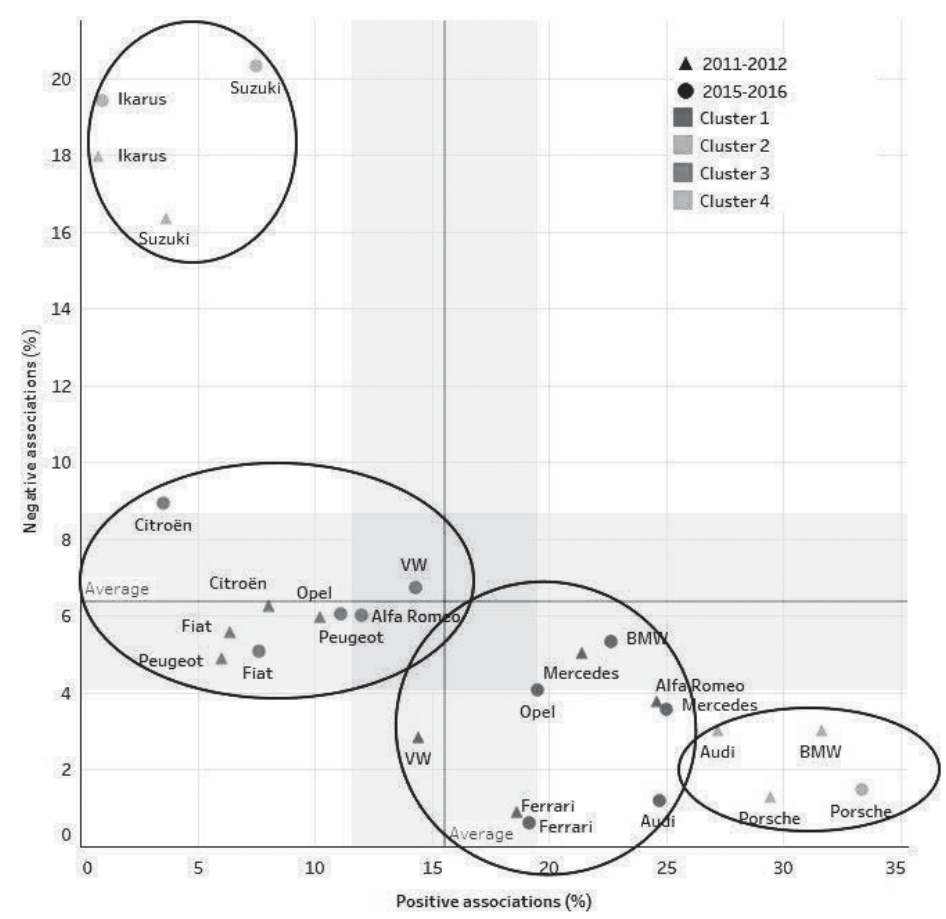

Note: Clusters: k-means clustering; algorithm used: Lloyd's algorithm with squared Euclidean distances; for the optimal number of clusters the Calinski-Harabasz criterion was used.

Source: own calculation.

brands are perceived more positively, while others are more negative; if changes occur, they are still positioned along one axis, meaning that neither negative associations are converted into positive one nor vice versa (Figures 6 and 7).

In the case of alcohol brands, three clusters can be seen: one with more positive associations, and two with mixed (positive and negative) associations. In the case of automotive brands, the distribution is different and involves four clusters: one with almost no positive but several negative associations, one with several positive and almost no negative associations, but there are also two mixed clusters: one with rather positive (Mercedes, Ferrari, etc.) and one with balanced associations (Citroën, Fiat, etc.). It is important to see that Ferrari again has a unique position: its position in the two datasets does not change.

What causes the positive and negative associations? When it comes to automotive brands, in most cases it could be user experience. Since we do not have any information on whether the respondents or their family owns one or several cars, and which brand they are, and since in most cases it is impossible to draw inferences from the associations about the ownership of a certain car brand, we compare the Hungarian car market and the association patterns found. 
TABLE 3: Car brands in Hungary

\begin{tabular}{|c|c|c|c|}
\hline \multicolumn{2}{|c|}{2011} & \multicolumn{2}{|c|}{2015} \\
\hline Brand & Quantity & Brand & Quantity \\
\hline Opel & 428,671 & Opel & 451,349 \\
\hline Suzuki & 401,300 & Suzuki & 404,694 \\
\hline Volkswagen & 263,869 & Volkswagen & 304,037 \\
\hline Ford & 227,515 & Ford & 256,178 \\
\hline Renault & 192,109 & Renault & 204,800 \\
\hline Škoda & 161,875 & Škoda & 171,495 \\
\hline Fiat & 130,109 & Toyota & 139,798 \\
\hline Toyota & 123,574 & Peugeot & 128,904 \\
\hline Peugeot & 120,576 & Fiat & 126,845 \\
\hline Lada & 104,533 & Citroën & 87,701 \\
\hline Citroën & 80,755 & BMW & 84,320 \\
\hline Daewoo & 69,684 & Audi & 80,432 \\
\hline Seat & 63,665 & Mercedes & 80,194 \\
\hline Mercedes & 55,981 & Seat & 66,752 \\
\hline Audi & 54,912 & Daewoo & 65,542 \\
\hline Nissan & 50,295 & Lada & 63,013 \\
\hline BMW & 49,970 & Nissan & 58,933 \\
\hline Honda & 49,098 & Honda & 56,870 \\
\hline Trabant & 37,435 & Mazda & 47,679 \\
\hline Chevrolet & 36,709 & Chevrolet & 38,922 \\
\hline
\end{tabular}

Source: Hungarian Central Statistical Office, Stock of passenger cars in Hungary by make (KSH gépkocsik 2017).

An overview of the Hungarian car market of 2011 and 2015, showing the brands and respective quantity, is summarized in Table 3. It is observable that value brands dominate the market, while premium brands are rather uncommon in both time periods. However, it is exactly those brands, which are uncommon on the market, that have rather positive associations. This indicates that the average citizen has no personal experience with these brands: he or she only knows the premium brands by name, some optical features, and properties which a premium brand must have to be called a premium brand - e.g., comfortable. The negative associations of premium brands are almost exclusively the ones connected to the "stereotypical" brand user.
On the contrary, value brands are common on the market and they elicit mixed associations, possibly depending on the personal experiences of their users. Some associations are certainly negative - those related to quality, for example. In the case of Suzuki, the common opinion of that time was that while the cars are not of the best quality, the engine itself is reliable. Likewise, Ikarus buses were not renowned for being comfortable. These former insights seem to be reflected in the associations. The results show that consumers tend to have their opinion of and associations to - brands that they do not actually own. In the case of premium brands, these associations could be more positive than the associations of the consumers who actually own the brand, with all their advantages and disadvantages.

It must be stated, however, that the hypothesis about positive and negative associations actually being based on user experience - however plausible the results and the data are - was not tested in the current experiment. These assumptions are indicative only and are not corroborated by research findings.

$\mathrm{H} 3$ is not accepted since brands could not be incorporated into disjoint clusters - namely, strong positive, strong negative, weak positive, and weak negative - and in each case, clusters were found to include balanced, mixed associations.

\subsection{Brand vs. product associations}

H4: Associations of the product and of the brand can be distinguished and they show segment-specific distribution.

In the 2011-2012, the Ferrari dataset elicited most associations to the brand (almost $60 \%$ of the associations were associations to the brand), whereas the former Hungarian bus brand Ikarus elicited the least associations to the brand (less than $10 \%)$. 
László Kovács

FIGURE 8: Brand and product associations in the 2011-2012 dataset - automotive brands

\section{Brand and product associations}

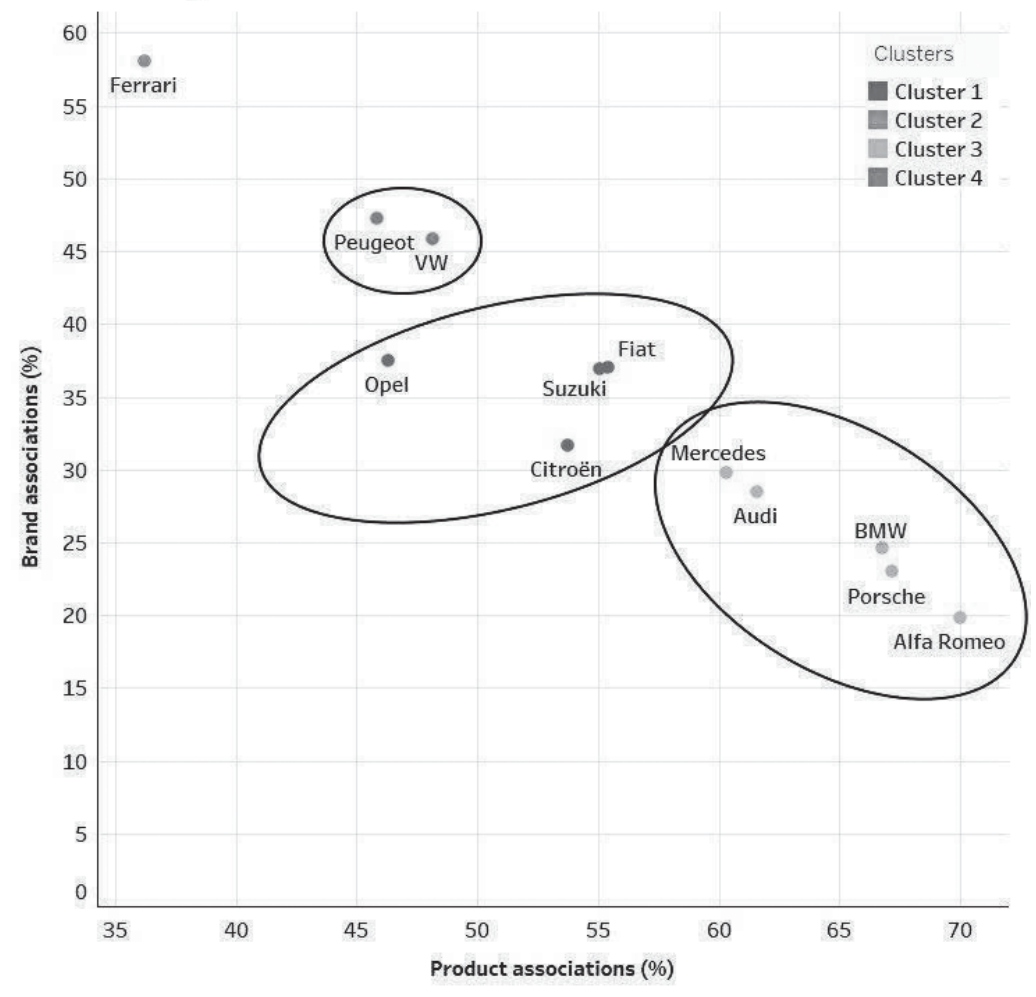

Note: Clusters: k-means clustering; algorithm used: Lloyd's algorithm with squared Euclidean distances; for the optimal number of clusters the Calinski-Harabasz criterion was used. Brand associations: main category I. brand associations; product associations: main category II.+III. product associations - objective + product associations - subjective.

Source: own calculation

Here are some examples from the collected data: brand associations to Ferrari are manifold; they are connected, for example, to the brand color (red), to the logo (horse). and to brand activities ensuring brand awareness (Formula 1). In the case of Peugeot, the association to the brand's unique characteristics is almost exclusively to the logo (lion) and some car models, such as the Peugeot 206. When it comes to VW, the associations are to specific models (e.g., Golf, Polo, Beetle, Passat) and to the name: Volkswagen (the complete name of the brand) and the Hungarian translation of the full German name Volkswagen: népautó - "people's car".
Premium automotive brands build one cluster, whereas value brands are distributed into two clusters. Ferrari stands alone as the only element of its cluster. But if Ferrari is neglected as an outlier and just two clusters are created, then those clusters are homogenous: one cluster includes all value brands and the other all premium brands.

Therefore, H4 was accepted since associations of the product and of the brand can be distinguished and they show segment-specific distribution.

In the next step, subjective (e.g., smell, price) and objective (e.g., ingredient, material) asso- 
ciations were compared, to test the following hypothesis:

H4.1: Product associations can be divided into objective and subjective associations.

As opposed to intuitive assumptions, alcohol brands have less subjective associations than do automotive brands (Figures 4 and 5, in detail Figure 9). These figures show that alcohol brands (with the exception of Unicum) are clustered together. It is also interesting to observe that premium automotive brands also seem to build their own group, without Ferrari however. Suzuki's closeness to this cluster can be explained by the fact that Suzuki was one of the first cars to have been produced in Hungary (production since 1992) and the first non-Eastern-bloc automobile brand bought in large quantities in Hungary after the political transition.
Looking closely at the collected data, the differences of subjective associations of automotive and alcohol brands can be explained partly by the fact that subjective characteristics of automotive brands are manifold. For instance, the latter include visual impressions such as design, sound, and characteristics such as speed, size, comfort, whereas alcohol brands have subjective characteristics almost exclusively linked to the taste of the drink, which gives rise to some managerial implications (see below).

It is also observable that similar brands - although with some outliers - seem to cluster together on the subjective/objective matrix. It seems that certain product categories are perceived along retained subjective and objective properties and that these specific combinations of properties influence a brand's cognitive position.

FIGURE 9: Percentage of subjective and objective product associations, 2011-2012 dataset

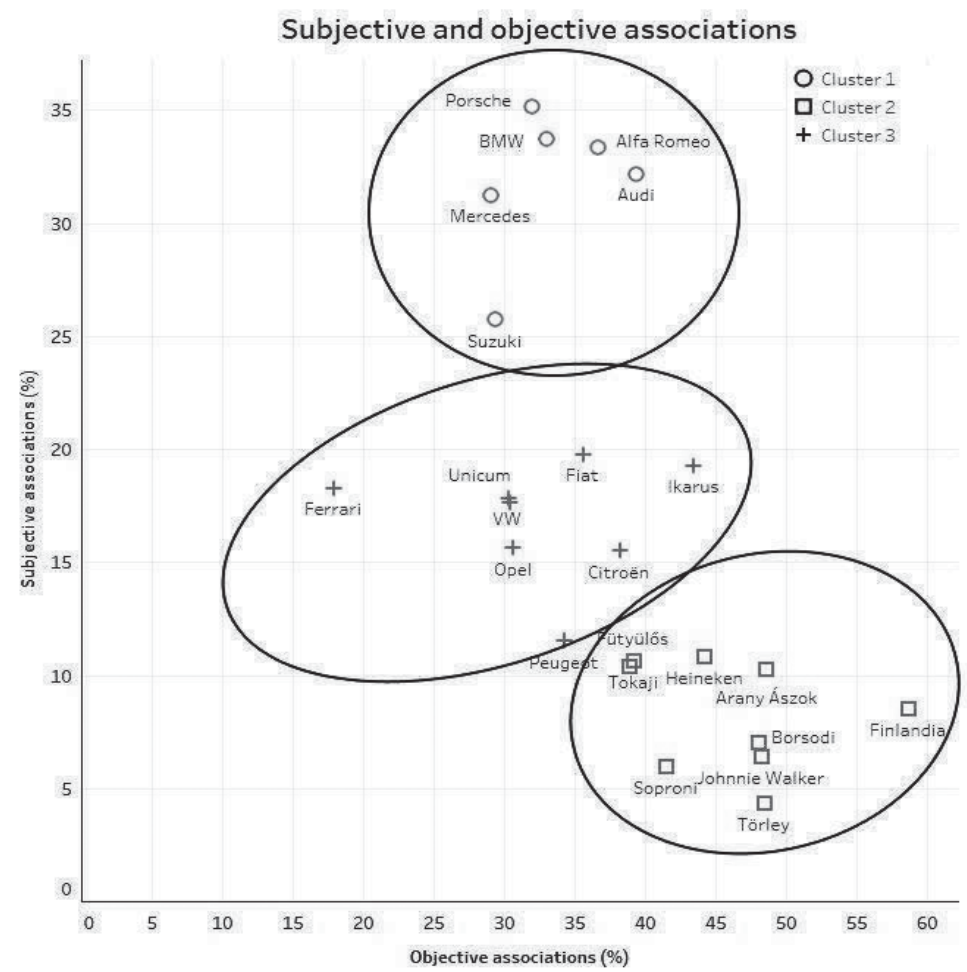

Clusters: k-means clustering; algorithm used: Lloyd's algorithm with squared Euclidean distances; for the optimal number one calculation. 


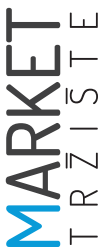

Thus, H4.1 is accepted because objective and subjective product associations have been found to exist and they show product category-specific distribution.

\subsection{Associations related to advertising}

H5: Associations are influenced by marketing communication, the influence is product category-dependent.

The analysis of associations to advertisements provides an interesting insight. In this case, we just highlight the three brands (Borsodi, Suzuki, Unicum) connected most strongly to advertising (Figure 10).
In all three analyzed brands, only one component of the advertisements was found to be responsible for high percentages of advertisement associations across the two datasets. In the case of Borsodi and Suzuki, strong associations are to their (former) slogans, "Az élet habos oldala" ("The foamy side of life") and "A mi autónk" ("Our car"), respectively. In the case of Unicum, it was a visual component of the advertisements: a drunken man's head appearing amid waves in the sea.

The slogan of Borsodi is more than a decade old, is still used and it rhymes to the Hungarian equivalent of "the sunny side of life" ("az élet napos oldala"). An earlier, autumn 2005 survey

FIGURE 10: Associations to advertisements: the tree brands with the strongest associations to advertisements

\section{Associations related to advertisement (\%)}

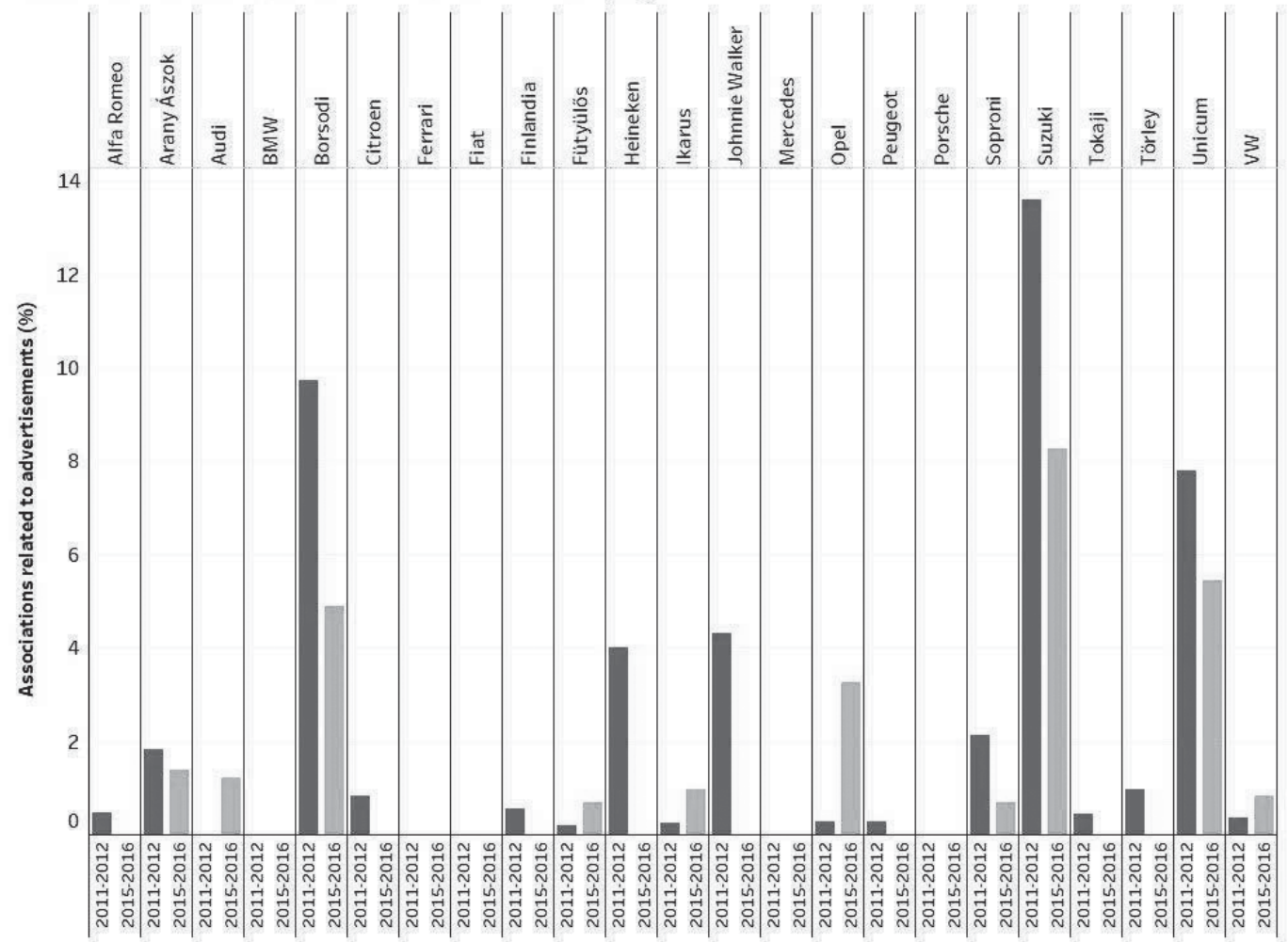

Source: own calculation. 
highlighted that, among beer brands, the advertisements of Borsodi with "The foamy side of life" slogan had been seen by most respondents $(21 \%)$, with the spots of Soproni scoring the second with $13 \%$, followed by Heineken, and Arany Ászok. Top of the mind brand awareness was $23 \%$ for Borsodi, followed by Soproni (14\%), Heineken (10\%) and Arany Ászok (8 \%) (Az élet habos oldala, 2005).

Suzuki used its slogan ("Our car") from the time the first Suzuki Swift cars were sold in Hungary (1992) until the early $21^{\text {st }}$ century. Although the slogan is not used any more, it seems to be engraved in the minds of the customers: even in 2018, the brand is called "our car" in the media (compare, e.g., Is Suzuki not our car anymore? - Már nem a Suzuki a mi autónk?, 2018).

Among the associations often mentioned is the famous advertising element of Unicum: a drunken man's head. The advertisement appeared for the first time in the early $20^{\text {th }}$ century -in 1909 - and was afterwards not only used in advertisements of the brand, but also appeared in caricatures, cartoons, and movies (Zwack, 2018; Az Unicum úszó emberes plakátja, 2018).

It can be seen that all three advertising elements were used for a long period of time, over more than 10 years. Although they appeared in different forms over that time, in combination with different messages, in different media, one of their key elements remained the same: the slogan and the picture. During those years, all three advertisement elements became widely known in Hungary and are now part of our shared culture and Hungarian identity - this is why they appear in a figurative sense in the news, or in films, or caricatures.

H5 was not accepted because the results corroborate that it is not the product category, but the advertising strategy that is responsible for associations to advertisements.

\section{CONCLUSION, MANAGERIAL IMPLICATIONS AND FUTURE RESEARCH}

\subsection{Conclusion}

The present paper provides an insight into brand association research. By describing a brand association study and presenting first comparative results across product categories, the paper showed how the method can be used for a better understanding of a brand's cognitive position. The two datasets - collected in 2011-2012 and in 2015-2016, respectively - enabled the capturing of an important characteristic of brand associations: the dynamics of change in brand associations.

It is important to emphasize that research on brand association is only able to show the current position of the brand names in a special cultural/linguistic and temporal context: thus, this present paper describes the associations for brands in Hungary and in Hungarian in the years 2011-2012 and 2015-2016.

The distribution of associations presented here (a strong first association followed by a much weaker second association) is common not only for brand names, but for common names too (Kovács, 2013; Utsumi, 2015). In this regard, brand names seem to collect associations in a similar manner to nouns. The strongest association was - with the exception of Ferrari - to the product category. This corresponds to the insights of Schmitt (2012), who designated the associations to the product category to be the most important associations of a brand.

As results of this research show, the associations of product brands change over time (see H2) and, as has been shown, the associations of a brand are not only created only by marketing instruments but also by personal experiences and by media news. This is in line with Batey (2008), Kastens and Lux (2014), and Kovács (2016), who pointed out that the meaning of a brand is not just the meaning that the brand's owner "puts" 


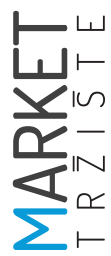

into the brand: rather, the real meaning is discussed by the society and is created in the mind of the consumer.

The latter position is easily accepted if we think of the brands that we do not like for some reason, and which we perceive as being other than the advertisements of the brands suggest. An advertisement for a product can, for example, underline its quality but, when compared to its price, customers may rate the quality as low rather than high. These experiences and preferences can be nested in society (e.g., something is "in") or they can originate from personal experiences with the brand (cf. Bauer, 2016). Thus, brands can be seen as mental constructs which have a negotiated meaning in society, and a personal meaning constructed in the mind of the consumer (cf. Batey, 2008; Kastens \& Lux, 2014).

It has been indicated that the brands which a consumer has personal experience with tend to have more negative associations than those he or she does not use. This is in line with the results of Low and Lamb (2000), who also found that "well-known brands tend to exhibit more developed brand association structures than unfamiliar brands" (Low \& Lamb, 2000: 361). According to our results, we can add to the argument of Low and Lamb, that brand users may produce more negative associations (as a facet of their more developed brand association structure) than non-users. Negative associations also differ between the value and premium segment of automotive brands: in the value segment, they describe quality and usage experiences, while in the premium segment, they represent stereotypical users. Positive associations emerge when the brand or the product is strong - even if the brand is not known closely, in which case, an idealized image of the brand and product arises. Mixed associations emerge mostly for value brands with average product properties.

The clusters of positive and negative associations correspond only in part to the emotional dimensions of consumer brand relationship of Fetscherin and Henrich (2014), which was dis- cussed earlier. Instead of four clusters - weak positive feeling, weak negative feelings, strong positive feelings, strong negative feelings towards a brand - the clusters in the present research study are different. For automotive brands, one includes very strongly positive, one strongly positive, one strongly negative, and one mixed associations. When it comes to alcohol brands, there is one strong positive cluster, and two clusters with mixed (positive and negative) associations. In view of present data, Fetscherin and Henrich's matrix cannot be confirmed by brand associations: in the case of automotive brands, there seems to be a more subtle differentiation than Fetscherin and Henrich's matrix suggests, whereas the differentiation for alcohol brands is weaker as just two of their matrix quadrants can be confirmed.

In testing $\mathrm{H} 4$, brand and product associations were separated and showed that their distribution is category-specific. Chen (2001) argued that brand associations are connected to brand equity, but he counted product-related associations to the brand's associations. In our paper, we have shown - similarly to Crawford Camiciottoli and others (2014) - that, by splitting up productand brand-related associations, a more detailed picture can be seen: some brands score high on brand attributes, while others score high on product attributes. The differences indicate that product- and brand-related associations should not be mixed up and that they should be analyzed separately since they are different facets of a "branded product", and high scores on these facets are helped by managerial decisions (see below).

The fact that value brands and premium brands build their own clusters in our mind shows that the brand values and product benefits are perceived by the costumer in similar ways within these two segments despite the fact that marketing communication, advertisement strategies, models etc. of those individual brands are different. This means also that the positioning as a value brand or as a premium brand raises certain expectations which are independent of 
recent marketing communications and actual product attributes. From this point of view, it can be explained why, for example, Volkswagen's Phaeton has not been a success and why its production was discontinued: despite the fact that Phaeton was positioned as Volkswagen's premium model, it is still a Volkswagen. The perception of Volkswagen as a value brand is thus grounded in the minds of the consumer, and marketing communication alone was not sufficient to change this deep-rooted perception for one model of the brand.

The results with regard to advertisements have more managerial than theoretical implications. They correspond the ground-breaking argument of Gardner and Levy (1955), in which they saw an advertisement as "part of a long-term investment in the reputation of the brand" (39). However, this is partly in contradiction to Keller (1998) since strong associations may arise as a result of marketing communication. When the red color of Ferrari is seen as part of the marketing communication of Ferrari (see di Montezemolo, 2003), then marketing communication is even able - over decades - to create the strongest association to a brand.

\subsection{Managerial implications}

Seeing the distribution of the strongest associations, a product category-specific approach is recommended: the second, third etc., associations of alcohol brands can be strengthened by "weakening" the first association to the product category. Weakening the association to the product category has small risks for well-known brands since they are already well-connected to the product category. Combining this recommendation with the results of $\mathrm{H} 4$ testing - that the perceived subjective characteristics of automotive brands are manifold, while those of alcohols are rather one-sided - opens up an opportunity for brand managers. By seeing the variety of subjective attributes an automotive brand can have and on which branding is built, alcoholic drinks can be branded in a similar way: not only according to taste - which by itself is sel- dom emphasized in advertisements - but also their smell or clarity, for example. This would facilitate the positioning and could form the basis for a unique selling proposition (USP). The effect and benefits could be compared to that of the German Babo beer brand, which - contrary to its competitors - sells its beer brand in blue, pink, and green color. In the specific case, an objective product property - color - is used for branding and as a USP (Babo beer, 2018).

The benefits of a strong association, which is not the product category, are manifold:

o it enables distinctive branding;

0 in advertisements, a given attribute that is also perceived by the consumer perceived can be emphasized;

- a strong characteristic of a product can be converted into a USP of the brand.

As seen in H1.1, a Japanese brand manufactured in Hungary is perceived partly as being Hungarian. This result suggests that a slogan which implicitly connects a brand to a country can have the effect of the brand being perceived as part of that given country, so using this technique, a favorably perceived country-of-origin can be communicated.

As shown by the results, associations change over time (H2), but they can also be changed by using different means: News in the media and personal experiences are just as responsible for associations as are advertisements and PR campaigns. This insight is especially important for service brands, such as a fast-food chain, where customers often deal with staff and draw their conclusions about the brand on the basis of their personal experiences.

$\mathrm{H} 3$ has shown the existence of positive and negative associations to all brands. Positive associations are important as they ensure brand loyalty; however, negative ones are even more important: they highlight brand or product properties which need to be improved in order to keep consumers satisfied. They also represent an opportunity for advertisements: when

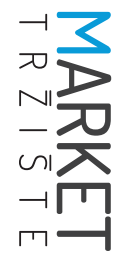


a well-known negative characteristic has been mended (e.g., quality improved), it could be explicitly communicated in advertisements. This shows consumers that the company is responsible - it addresses problem areas, instead of avoiding them.

It has been seen that some brands score high on brand associations and others on product associations, so these insights can be used to decide on brand and product strategy. Strong associations to the brand ensure brand loyalty - in such cases, visual properties are harder to change, while product properties play a less important role (Keller, 1998). If the associations to product properties are strong, it is not advisable to change the product itself; however, it is easy to change the packaging or other visual brand characteristics (Keller, 1998; see also the wellknown case of New Coke). Thus, the insights gained from associations can determine the strategy for further branding, product changes, or the focus of advertisements, emphasizing brand or product attributes.

An important insight is provided by H5: It seems that brand slogans and advertisements elements used consequently for a longer period of time (over decades) are deeper engraved in our minds, they even seem to become common cultural knowledge. This also points to the fact that changing core advertising elements - like slogans or some visuals - is advisable only in the cases when this is inevitable, as every change carries the risk of a loss of one of the brand's most remembered core elements.

\subsection{Future research}

The possibilities for future research are manifold. The opportunities for further analysis of the collected datasets can be summarized under the following research streams:

\section{Analyzing the associative structure of different product categories.}

It could be useful to have comparisons of associations across product categories to see whether, in some product categories, brand or prod- uct associations are stronger or to see whether subjective or objective associations prevail. The comparison and insight from other product categories could help brand managers in making branding decisions. The possible analyses include:

o Analysis of different product groups, e.g., cosmetics, food, or non-alcoholic drinks, to see how their associative structures differ from each other and from alcoholic drinks or consumer durables like cars.

- Analyzing and comparing the association structures of service brands to those of product brands to see what kind of associations prevail in both categories. This is especially important in cases where product and service exist together (as in fast-food) and where the analysis could show which part of the brand (product or service) is strong and which one needs to be improved.

- Analyzing and comparing which associations often appear together in a product category helps with branding or advertising decisions, since the associations appearing together can elicit and reinforce each other.

\section{Analysis according to consumer segments}

It could be useful to discover the patterns in associations which correspond to a specific consumer segment. For example, when a consumer segment connects color as a distinctive feature to a product category or brand, then color needs to be emphasized in advertisements for this consumer segment:

- Analysis of associations according to a specific consumer segment, including gender-specific differences in associative structures or identifying patterns according to the age group.

o This method can be used as a follow-up to advertisements by comparing associations to the advertisement in different generational cohorts (cf. De Run \& Ting, 2013). Thus, the impact of advertisements can be measured and which communicated fea- 
tures of the brand are integrated into the long-time memory analyzed.

- The analysis of the association patterns of individuals can be also useful. For example, it can be seen, what features of a product are important or which product feature goes with another feature. Thanks to such insights, automotive brands could develop a model variant which holds exactly those features that individuals perceive to be the most important. In the age of individualized production, this gives a competitive advantage to a company.

\section{Consumer behavior and associations}

An important question concerns how consumer experiences influence associations. As seen in $\mathrm{H} 3$, it seems that negative associations arise when consumers have their own (negative) experiences with a brand or a product. Identifying the attributes of a product which a consumer finds most unsatisfying provides the opportunity to improve the given attribute in order to increase consumer satisfaction.

\section{Facilitate brand management decisions}

Some implications and research possibilities are more practical than others and can be used to improve the branding strategy even without comparing them to other product categories. One such possibility is to compare the associations to advertisements of the brand with the advertising strategy of that brand (see H5) to see what kind of associations are created by different advertising campaigns.

The ultimate goal - and a research plan for decades - would be the possibility to point out the influencing factors and mechanisms which create and define associations (cf. Kovács, 2016). With this knowledge brand associations could be created, deleted, or altered cost-effectively, having far-reaching managerial implications.

\section{Acknowledgment}

The research was supported by the Institute of Advanced Studies Kőszeg.

\section{References}

1. Aaker, D. A. (1991). Managing Brand Equity. New York, NY: Free Press.

2. Aaker, D. A., Kumar, V., \& Day, G. S. (2001). Marketing research. Hoboken: John Wiley \& Sons.

3. Az élet habos oldala (2005). Available at https://www.portfolio.hu/vallalatok/az-elet-habos-oldala-vezet-a-borsodi.61398.html

4. Babo beer (2018). Available at https://baboblue.com/

5. Batey, M. (2008). Brand Meaning. New York, NY: Routledge.

6. Bauer A. (2016). A márka fogalma. In: A. Bauer \& K. Kolos (eds.), Márkamenedzsment (pp. 17-34). Budapest: Akadémiai.

7. Broniarczyk, S. M., \& Alba, J. W. (1994). The importance of the brand in brand extension. Journal of Marketing Research, 31(2), 214-228.

8. Chen, A. C-H. (2001). Using free association to examine the relationship between the characteristics of brand associations and brand equity. Journal of Product \& Brand Management, 10(7), 439-451.

9. Crawford Camiciottoli, B., Ranfagni S., \& Guercini, S. (2014). Exploring brand associations: an innovative methodological approach. European Journal of Marketing 48(5/6), 1092-1112.

10. Csordás, H., \& Ziegler, Z. (forthcoming) Particularist Understanding of CSR Marketing Visual Arguments. In: P. Barrotta \& G. Scarafile (eds.), Interdisciplinarity and Controversies. Amsterdam: John Benjamins. 
11. De Deyne, S, Navarro D. J., \& Storms G. (2013). Better explanations of lexical and semantic cognition using networks derived from continued rather than single-word associations. Behavior Research Methods, 45(2), 480-498.

12. De Run, E. C., \& Ting, H. (2013). Generational Cohorts and Their Attitudes toward Advertising. Market-Tržište, 25(2), 143-160.

13. del Rió, A. B., Vázquez R., \& Iglesias R. (2001). The effects of brand associations on consumer response. Journal of Consumer Marketing, 18(5), 410-425.

14. di Montezemolo, L. (2003). Ferrari and Maserati. In: R. Kalmbach \& B. Gottschalk (eds.), Markenmanagement in der Automobilindustrie (pp. 255-278). Ottobrunn: Auto Business Verlag.

15. East, R., Hammond, K., \& Lomax, W. (2008). Measuring the impact of positive and negative word of mouth on brand purchase probability. International Journal of Research in Marketing, 25(3), 215224.

16. Esch, F-R. (2004). Strategie und Technik der Markenführung. München: Franz Vahlen.

17. Fetscherin, M., \& Heinrich, D. (2014). Consumer brand relationships: A research landscape. Journal of Brand Management, 21(5), 366-371.

18. Find Clusters in Data (2018). Available at https://onlinehelp.tableau.com/v2018.2/public/desktop/en-us/help.html\#clustering.html

19. Franzen, G., \& Bouwman, M. (2001). The Mental World of Brands. Henley-on-Thames: World Advertising Research Center.

20. French, A., \& Smith, G. (2013). Measuring brand association strength: a consumer based brand equity approach. European Journal of Marketing, 47(8), 1356-1367.

21. Gardner, B. B., \& Levy, S. J. (1955). The product and the brand. Harvard Business Review, March-April, 33-39.

22. Gordon, J., \& Yoshida, M. (2016). The Development of Brand Association Measures in Multiple Product Categories: New Findings and Implications for Goods and Service Brands. International Journal of Business Administration, 7(3), 140-152.

23. Ikarus (2016). Available at http://www.ikarus.hu/

24. Kapferer, J-N. (2008). The New Strategic Brand Management. London: Kogan Page.

25. Kastens, I. E. (2008). Linguistische Markenführung. Münster: LIT.

26. Kastens, I. E., \& Lux, P. G. (2014). Das Aushandlungs-Paradigma der Marke. Wiesbaden: Springer Gabler.

27. Keller, K. L. (1993). Conceptualizing, Measuring and Managing Customer-Based Brand Equity. Journal of Marketing, 57(1), 1-22.

28. Keller, K. L. (1998). Strategic Brand Management. New Jersey, NJ: Prentice Hall.

29. Keller, K. L. (2013). Strategic Brand Management. Harlow: Pearson.

30. Kotler, P., \& Pfoertsch, W. (2006). B2B Brand Management. Berlin/Heidelberg: Springer.

31. Kotler, P., \& Pfoertsch, W. (2010). Ingredient Branding. Berlin/Hedielberg: Springer.

32. Kovács, L. (2013). Fogalmi rendszerek és lexikai hálózatok a mentális lexikonban. Budapest: Tinta.

33. Kovács, L. (2016). Marke im Kopf: ein kognitionslinguistischer Blick auf Markenbilder. In: I. E. Kastens \& A. Busch (eds.), Handbuch Wirtschaftskommunikation (pp. 258-293), Tübingen: Narr Francke Attempto.

34. Kovács, L. (2017). Márka és márkanév. Budapest: Tinta.

35. KSH gépkocsik (2017). Available at http://www.ksh.hu/docs/eng/xstadat/xstadat_annual/i_ ode001b.html

36. Kunkel, T., Doyle, J. P., Funk, D. C., Du, J., \& McDonald, H. (2016). The Development and Change of Brand Associations and Their Influence on Team Loyalty Over Time. Journal of Sport Management, 30, 117-134. 
37. Low, G. S., \& Lamb, C. W. (2000). The Measurement and Dimensionality of Brand Associations. Journal of Product \& Brand Management, 9(6), 350-370.

38. Malhotra, N. K., \& Birks, D. F. (2007). Marketing Research: An Applied Approach. Harlow: Prentice Hall.

39. Már nem a Suzuki a mi autónk? (2018). Available at https://privatbankar.hu/vasarlo/mar-nem-asuzuki-a-mi-autonk-megvan-mi-a-magyarok-kedvence-320209

40. Meffert, H., Burmann, C., \& Koers, M. (2002). Stellenwert und Gegenstand des Markenmanagement. In: H. Meffert, C. Burmann \& M. Koers (eds.), Markenmanagement (pp. 3-15). Wiesbaden: Gabler.

41. Ozretić Došen, Đ. (2014). Climbing the Brand Ladder: From Fashion Accessory to Distinctive, Country-Of-Origin Brand. Journal of Euromarketing, 23(1/2), 74-84.

42. Schmitt, B. (2012). The consumer psychology of brands. Journal of Consumer Psychology, 22(1), 7-17.

43. Utsumi, A. (2015). A Complex Network Approach to Distributional Semantic Models. PLoS One, 10(8), e0136277.

44. Zwack (2018). Available at https://zwackunicum.hu/hu/cegunk/zwack-tortenet/

\section{Appendix I.}

The list of brand names in the 2011-2012 and 2015-2016 data collection period. The list contains international (global) and local (Hungarian) brands.

\begin{tabular}{|l|}
\hline adidas \\
\hline Aldi \\
\hline Alfa Romeo \\
\hline Arany Ászok \\
\hline Astor \\
\hline Auchan \\
\hline Audi \\
\hline Avon \\
\hline Blikk \\
\hline BMW \\
\hline Boci \\
\hline Borsodi \\
\hline Bosch \\
\hline Budapest Bank \\
\hline C\&A \\
\hline Canon \\
\hline CBA \\
\hline Citroën \\
\hline Coca-Cola \\
\hline Coop \\
\hline Cosmopolitan \\
\hline Danone \\
\hline Délhús \\
\hline Dior \\
\hline Dolce\&Gabbana \\
\hline
\end{tabular}

\begin{tabular}{|l|}
\hline Dove \\
\hline Erste \\
\hline Fa \\
\hline Facebook \\
\hline Ferrari \\
\hline Ferrero \\
\hline Fiat \\
\hline Finlandia \\
\hline Freemail \\
\hline Fütyülös \\
\hline Garnier \\
\hline Glamour \\
\hline Google \\
\hline Gucci \\
\hline Györi Édes \\
\hline Haribo \\
\hline Heineken \\
\hline Herendi \\
\hline HP \\
\hline HVG \\
\hline Ikarus \\
\hline Index \\
\hline Iwiw \\
\hline Johnnie Walker \\
\hline Joy \\
\hline
\end{tabular}

\begin{tabular}{|l|}
\hline K\&H \\
\hline Knorr \\
\hline Labello \\
\hline LG \\
\hline Lidl \\
\hline L'Oreal \\
\hline Maggi \\
\hline Marc \\
\hline Max Factor \\
\hline Maybelline \\
\hline Mercedes \\
\hline Metro \\
\hline Milka \\
\hline MKB \\
\hline Nestlé \\
\hline New Yorker \\
\hline Nike \\
\hline Nivea \\
\hline Nők Lapja \\
\hline Nokia \\
\hline Obi \\
\hline Opel \\
\hline OTP \\
\hline Pepsi \\
\hline Peugeot \\
\hline
\end{tabular}

\begin{tabular}{|l|}
\hline Philips \\
\hline Pick \\
\hline Porsche \\
\hline Puma \\
\hline Raiffeisen \\
\hline S. Oliver \\
\hline Samsung \\
\hline Schauma \\
\hline Siemens \\
\hline Sony \\
\hline Soproni \\
\hline Spar \\
\hline Sport szelet \\
\hline Story \\
\hline Suzuki \\
\hline Tesco \\
\hline Tisza \\
\hline Tokaji \\
\hline Törley \\
\hline Unicredit \\
\hline Unicum \\
\hline Univer \\
\hline Versace \\
\hline VW \\
\hline YouTube \\
\hline
\end{tabular}

